\title{
AZ ÁLLAM MINT URALMI FORMA: A POLITIKAELMÉLET NÉZŐPONTJA
}

\author{
Balázs Zoltán* \\ (Budapesti Corvinus Egyetem, MTA TK Politikatudományi Intézet)
}

\begin{abstract}
A tanulmány beérkezett: 2019. április 23., opponálás: 2019. április 30 - 2019. május 21., véglegesítve: 2019. június 2.
\end{abstract}

\begin{abstract}
ÖSSZEFOGLALÓ
Egy politikai döntés nyomán Magyarországon hosszú évtizedek múltán ismét létezik államtudomány, mégpedig osztatlan egyetemi szak formájában is. Bár a rendszerváltás után több államtudományi könyv, tankönyv is megjelent, ezek a politikatudomány részéról kevés figyelemben részesültek. Az új helyzetben azonban szükségesnek látszik tisztázni, hogy a politikaelmélet milyen módon értelmezi és magyarázza az államot. A jelen tanulmány egy ilyen értelmezési kísérlet. Alapállítása, hogy az állam az uralom speciális formája (ennek alighanem máig legmeggyőzőbb igazolása Thomas Hobbes nevéhez köthető). Ebből következik, hogy a politikai típusú társadalmi koordináció, vagyis a hatalomnak való engedelmeskedés indokának szabad vitatása megelőzi az államot. Ugyanakkor az állam pontosan azért sikeres és meggyőző igazolás, mert - ahogy Hobbes magyarázatából adódik - képes kiiktatni a politikai szabadságot és a velejáró konfliktusokat. Ezért a politikaelmélet, mint a szabad vita filozófiai kerete, egyrészt mindig kihívás az állam számára; másrészt viszont könnyen szolgálatába is szegődhet. Ez utóbbira a liberális-funkcionalista (elosztási feladatokra egyszerüsített) felfogás az egyik, a XX. század első felében dívó, potenciálisan azonban ma is vonzó állammisztika a másik példa.
\end{abstract}

Kulcsszavak: állam - hatalom - uralom — politikaelmélet — Hobbes,

Platón Politeia címú múvét $A z$ állam-nak fordítani tudvalevőleg anakronizmus. Cicero De re publica címú töredékes, klasszikus párbeszédét $A z$ államról-nak

* A tanulmány eredeti változata a Nemzeti Közszolgálati Egyetem államtudományi konferenciáján hangzott el 2017. november 22-én. A szöveg igen jelentősen bővült és változott. A megjegyzéseikért köszönet illeti Horváth Szilviát, Szücs Zoltán Gábort, valamint a Politikatudományi Szemle két anonim bírálóját. 
fordítani ugyancsak. Sem a görög, sem a római politikai tapasztalat nem ismerte az államot, és a társadalmat sem. De természetesen ismerte az uralom és a kormányzás különféle típusait, ismerte az autarkeia, az önkormányzó polisz fogalmát, el tudta különíteni a közhatalom egyes fajtáit és kompetenciáit, továbbá elég sokat tudott arról, hogy a különféle népek különféle szokások és intézmények szerint élnek; tehát a nép valamilyen kollektív fogalom, noha a népek összességére mint emberiségre inkább mitológiai értelemben gondolt. Uralom, kormányzás, polisz (civitas), nép, közösség - nagyjából ezekből az alapvető kategóriákból építkezik a klasszikus politikai gondolkodás. ${ }^{1} \mathrm{~S}$ ezekre az ôsi, civilizációnkat mélyen meghatározó fogalmakra és ismeretkörökre épít, ezekre reflektál a modern politikai gondolkodás is, függetlenül attól, hogy milyen különbséget teszünk - ha teszünk - politikaelmélet, politikai filozófia, netán egyszerúen a politikai dolgokról való gondolkodás között. ${ }^{2}$ Ezért az állam mint probléma, jelenség és fogalom a gyakorlati filozófia, ha tetszik, a politikai filozófia (politikai gondolkodás, politikaelmélet) egyik fontos, de a felsorolt, továbbra is releváns témákkal egyenrangú és azokkal összefüggésben értelmezendő témája.

Modern kollektív fogalmaink, amelyek jóval számosabbak, mint a klasszikus kor fogalmai, mintegy szétosztották, szétparcellázták a kollektívum vagy a közösség politikai természetét. Mit jelent ez? A szuverenitás például leginkább jogelméleti; a társadalom és a közösség társadalomtudományos fogalommá vált; a politikai gondolkodást a demokrácia foglalta le (illetve egyéb rendszerek, jellemzően ellenfogalomként); az állam pedig leginkább igazgatási fogalom lett. Az államelmélet múvelői ezen úgy igyekeznek változtatni, hogy az államot tekintik valamiféle gyưjtőfogalomnak és témának. „Államtan vagy államelmélet: az állam egészének, valamint az azzal szorosan összefüggő társadalmi, politikai, jogi, gazdasági és erkölcsi jelenségeknek az elmélete, mely tárgyáról általános ismereteket kíván nyújtani" (Takács et al., 2016: 12., eredeti kiemelés). Az intenció világos: mivel az állammal igazán minden összefügg, ami az emberek együttélésében fölmerülhet, az államtudomány vagy -elmélet mindebben illetékes. „A különböző társadalmi jelenségeket, objektivációkat, intézményeket több oldalról lehet vizsgálni [...] Ez azonban nem eredményezi azt, hogy ezzel teljes képet lehet szerezni róla, és meg van oldva a vizsgálata, mivel a különböző megközelítések sajátos nézőpontúak, nem az állam belső sajátosságait, rá jellemző (sui generis) vonásait tárják föl" (Samu, 2000: 19.). Amire tehát szükség van, az „az állami élet különböző oldalainak, belső vonásainak," „törvényszerűségeinek" a kutatása (Samu, 1992: 12.). Ez azt jelentené, hogy az állam sajátos lényeggel rendelkező valami. Az előbbi megfogalmazás viszont az államot afféle gyújtőfogalomként kezeli, amely sokféle, egymással inkább történeti értelemben összefüggő intézményt, fogalmat, eljárást, jogot foglal magába. A két megközelítés nagyon is inkoherens. Ez nem álprobléma vagy öncélú spekuláció. Az államnak valóban van vagy lehet köze 
mindenhez; de ez igaz a politikára is. Míg azonban a politikai minőség mibenléte, vagyis az a kérdés, hogy mi tesz valamit politikaivá, régóta elég jól körülírt probléma, addig az állam mibenléte nem az. Helyesebben tekinthetjük történetileg esetleges intézményes uralomnak, csakhogy akkor az állam léte, múködése a politikai gondolkodás egyik részkérdése. A politikai-gyakorlati gondolkodás és a rá vonatkozó, belőle táplálkozó elmélet ugyanis minden olyan további részelméletet, reflexiót tartalmaz, amelyben kollektív fogalmak révén a közösség számára releváns empirikus és normatív állítások tehetők és megvitathatók. Ha ezt nem fogadjuk el, vagyis az állam valamilyen mélyebb lényegét (államiságot?) igyekszünk megkeresni, akkor könnyen tévedünk homályos, ha ugyan nem misztikus utakra.

Emiatt kell körültekintően értelmezni - legalábbis mostani szempontunkból - például azt a felfogást is, amelyet a Bihari Mihály és Pokol Béla által írt tankönyv mutat be (Bihari-Pokol, 2009). Eszerint ugyanis a politika elmélete sem más, mint a szféraként vagy alrendszerként elkülönült politika elmélete. Ez a felfogás bizonyos intézmények, cselekvők és jelenségek (pártok, mozgalmak, politikai verseny, hatalmi harc, politikai kormányzás) révén határozza meg a politikai alrendszert. Igaz, ebből az is adódik, hogy a politika mellett az állam is elkülönül, s lényegében a közigazgatásra szúkül. A könyv legalábbis ezt állítja, s ezért - egyébként nagyon konzisztensen - arra a következtetésre is jut, hogy az állam voltaképpen fölösleges kategória. Ez azonban így nem pontos, helyesebben félrevezető lehet: semmi elvi akadálya nincs, hogy a közigazgatás egy bizonyos politikaelméleti modellben politikai gyökerú intézményként, államként szerepeljen. Éppen az az egyik érdekes politikaelméleti kérdés, hogy miért, mikor, milyen indokokkal hivatkoznak teoretikusok, politikusok, polgárok az államra. Az idézett, befolyásos könyvben adott értelmezés bizonyos történetileg erősen kötött intézmények, cselekvők, jelenségek révén írja le a politikai alrendszert, s ezért az értelmezés érvényessége is szúk. A politikaelmélet sokkal tágabb. Nem a politikai szféra vagy alrendszer elmélete, hanem a már említett kollektív kategóriákban való gondolkodás elmélete. Ahogy láttuk, éppen ezért tágabb és mélyebb, mint az államelmélet, még akkor is, ha az államelméletet nagyon kiterjesztően fogalmazzuk meg.

Ezt a logikát egy helyen az államelmélet múvelője is elfogadja. Ezt írja: „[a] politikai filozófia keretei között az állami intézményrend struktúrájának és múködésének elemzésén túl, sőt azokat megelőzve mindenekelőtt az ember és politika viszonyát vizsgálják, figyelemmel az azokkal összefüggésben álló fontosnak gondolt eszmékre és jelenségekre (igazságosság, demokrácia, jogok, tudás, stb.), a politika és az erkölcs viszonyára, valamint a valóságos és lehetséges történelmi tendenciákra is" (Takács et al., 2016: 60., eredeti kiemelés). ${ }^{3}$ Bár az idézetben a politikai filozófia megjelölés szerepel, de a felsorolt témák valójában a tágabb politikaelméletre utalnak. Egyetérthetünk azzal, hogy míg az állam a maga történeti valóságában viszonylag kései jelenség, addig a po- 
litikai gondolkodás és a politikaelmélet viszont régebbi, tematikáját tekintve pedig tágabb. A politikaelmélet felől nézve az állam tehát csak egyike a kollektív és individuális cselekvőre és cselekvésre vonatkozó megfontolásoknak és értelmezési kereteknek, éspedig nem csak történeti késeisége miatt, hanem elméleti korlátai és függősége miatt is. Ezért viszont nem fogadható el az alábbi megfogalmazás, amely nagyvonalúnak hat ugyan, de félrevezető: „Az államelméletek története azt mutatja: a fogalomképzés egyik kézenfekvő lehetôsége az, hogy az államban elsősorban az azt alkotó polgárok közösségét lássuk. Ebben az értelemben az állam politikai közösség, vagy egy cizelláltabb - és átgondolt társadalomelméleti előfeltevésekre utaló - megfogalmazás szerint a polgárok valamilyen politikainak nevezhető célból történt társulása. Ide sorolhatók azok az elgondolások is, amelyek szerint az állam "politikai társadalom «" (Egresi et al.: 194., eredeti kiemelés). A szöveg úgy folytatódik, hogy az állam ilyen közösségelvű felfogása átadta később a helyét az állam intézményi felfogásának. Csakhogy amíg nincs államfogalom, addig fölösleges azon spekulálni, hogy ha lett volna, akkor mit jelentett volna, vagy mit értettek volna rajta. Az állam fogalmának használata a hivatkozott korszakokra nem csak anakronizmus, hanem, ahogy látjuk, elméletileg is redundáns, mivel a mai értelmezés számára sem ígér fontos belátásokat.

Kétségtelen, hogy a mértékadó politikai filozófiai szakfolyóiratok ma ritkán tárgyalják az államot, vagy talán helyesebb úgy fogalmazni, hogy az állam mint gyakorlati filozófiai téma a tágabban értelmezett politikaelmélet más szektoraiban szerepel: azokban, ahol az alkotmányos elvekről, a kormányzásról, a jogelméletről van szó. A különböző felségterületek határairól való elvont elmélkedés azonban érdektelen és terméketlen téma. Ezért, ahogy a tanulmány elején jeleztem, a politikaelmélet, a politikai filozófia, a politikáról való gondolkodás közötti különbségekkel sem érdemes foglalkozni. Egyszerúen abból indulok ki, hogy a gyakorlati filozófiának az individuális és a kollektív cselekvőre és cselekvésre, valamint ezek kapcsolatára vonatkozó analitikus és normatív belátásai és megfontolásai között az állam eredetére, konstitúciójára, téloszára nézve is releváns állításokat találunk, illetve ilyeneket kimondhatunk. Ebben a tanulmányban három ilyen állítást teszek, s igyekszem érvelni mellettük. Az első, hogy a politikaelmélet az államot uralmi formaként kezeli, amely történetileg meghatározható folyamatok és elméleti belátások révén alakult ki. Az elméleti belátások közül kulcsfontosságú, hogy az állam mint uralmi forma engedelmességre épül, engedelmeskedést vár el, amit viszont valamilyen politikai indokolással vagy igazolással kell alátámasztania. Ennyiben az állam léte már föltételezi a normativitást. A második állítás az, hogy ez a politikai indokolás sajátos módon éppen a politikai viták megelőzését szolgálja, azaz negatív igazolásról van szó. Az államnak joga és kötelessége a politikai konfliktusok eszkalálódását megakadályozni. Ezért tûnhet úgy, hogy az állam megelőzi a politikát. Ez azonban félreértés. Nem az állam húzza meg a 
politika határait, nem a politika különül el az államtól (vagy az államban), hanem fordítva. A politikaelmélet, amely az igazolásra figyel, ezért pontosabb és helyesebb képet ad az állam szerepéről és politikai funkciójáról. Sőt, ezzel érkezünk el a harmadik állításig, ennek révén fontos kritikai funkciót is betölt, amennyiben két lehetséges politikai visszaélésre időben figyelmeztet. Az egyik a normativitás abszolutizálása: amennyiben az állam valamilyen végérvényesen helyes politikai normát követ (például az igazságosságot), annyiban minden olyan politikai, politikaelméleti, normatív vitát, ha nem is betilthat, de szükségtelenné és irrelevánssá nyilváníthat, amely ezt az alapnormát megkérdőjelezi. Valójában a politika mindig feszegetni fogja az állam politikai alapjait, s ezt csak zsarnokság árán lehetne teljesen vagy hatékonyan megakadályozni. A másik visszaélés ennek ellentéte: az állam minden aktusa, cselekedete, az iránta való lojalitás válik abszolút értékké vagy normává, a politika mintegy átjárja az állam minden eresztékét, az eredmény pedig egy misztikus vagy mitizált államfogalom, amely pontosan ugyanúgy fenyeget zsarnoksággal, mint az előző visszaélés. A politikaelmélet tudományos, erkölcsi, s persze politikai kötelessége, hogy ezekre a veszélyekre figyelmeztessen, azzal, hogy a politika és az állam közötti viszonyról valós és hiteles képet nyújt.

\section{II.}

Alaptételem a következő: az államra a politikaelmélet leginkább uralomforma gyanánt tekint. Triviális, hogy az államnak nagyon is köze van az uralomhoz vagy hatalomhoz. Hogy ez a kapcsolat mennyiben és hogyan lényegi, az vitatható, de a fontosságát az államelmélet múvelői sem tagadják. Samu Mihály szerint „[a]z állam a társadalom egészén belül elsősorban mint hatalmi tényező jelentkezik; lényeges vonásai a hatalom jellegétôl függenek. [...] Az állam konkrét történetisége is azt mutatja, hogy mint specifikus hatalmi viszony és intézmény létezik, s egyben a különböző hatalomfajták koncentrátuma." (Samu, 1992: 15.). Kevésbé világosan fogalmaz Takács Péter, de ő is egyértelmúvé teszi, hogy az állam és a hatalom vagy uralom szoros kapcsolata tény. ${ }^{4} \mathrm{Ha}$ ez így van, akkor a hatalom vagy uralom természetrajza és igazolása (az igazolás mindig része a magyarázatnak) szintén megelőzi az államra vonatkozó további kérdéseket. ${ }^{5}$ Ezért általánosságban azt mondhatjuk, hogy sokféleképpen lehet uralkodni emberek csoportjain, sokféleképpen lehet engedelmeskedni a vezetőnek, s ezek egyik formája vagy módja az állam, ahogyan azt ma közönségesen értjük. A politikaelmélet számára nem okoz problémát, hogy különbséget tegyen állami és nem állami uralmi formák között, s persze az sem, hogy ezeken belül további megkülönböztetésekkel éljen. Amikor az államtudományt Magyarországon fölszámolták, egy bizonyos szempontból helyesen tették: ami ugyanis a valóságban következett, az nem az állam, hanem az úgynevezett pártállam 
uralma volt. (Más kérdés, hogy ezzel egyidejúleg a politikatudomány is ellehetetlenült, hiszen a rezsim önmaga uralmi valóságát is kizárólag saját doktrínája szerint - gondoljunk a proletárdiktatúra, majd a "párt vezető szerepe," a "szövetségi politika," a "demokratikus centralizmus" fogalmaira - kívánta bemutatni és értelmezni.) Sem időben, sem térben nem kell tehát messzire mennünk, hogy az állam mint uralmi forma esetlegességét belássuk: közvetlen tapasztalatunk is van róla. ${ }^{6}$

Azonban az államelmélet - legalábbis ahogyan az a mai magyar szakirodalomban megjelenik - nem, vagy csak érintőlegesen foglalkozik az uralom vagy hatalom természetével, és igazolásának kérdésével. Elméletismertetésekkel ezt a feladatot nem lehet letudni. ${ }^{7}$ Az sem szerencsés, ha az autoritás elemzéséből indulunk ki, mintegy eleve megoldottnak véve a hatalom, uralom, erőszak és tekintély (autoritás) kapcsolatának problémáját. ${ }^{8}$ A politikaelmélet számára viszont ezek a primér kérdések. Ezért a politikaelméleti feladatot előbb el kell végezni, mielőtt az államra rátérhetnénk. ${ }^{9}$

Bármilyen irányból indulunk is el az állam felé, előbb föl kell tételeznünk tehát, hogy már létezik válasz arra a kérdésre, hogy miért kell engedelmeskednünk a kormányzatnak, a közhatalomnak, vagy éppen az államnak (már ahol ez a megjelenési forma). S persze csak olyan válasz fogadható el, amelyben az igazolás, azaz a normatív aspektus nincs fölszámolva. Más szóval minden olyan hatalomelmélet és engedelmeskedés-magyarázat, amelyben a kérdés eleve értelmetlennek látszik, mivel az engedelmeskedés merő automatizmus vagy strukturális jelenség, a politikaelmélet felöl nézve nem egyeztethető össze az állam létével. Egyszerúbb szavakkal kifejezve akkor beszélhetünk államról mint uralmi formáról, ha rákérdezhetünk az engedelmeskedés indokára, s arra komolyan vehető választ remélhetünk. Ez pedig föltételezi, hogy az egyéni cselekvők számára megvan az igazolás ellenőrzésének szabadsága.

Hangsúlyozni kell, hogy ezzel nem zárjuk ki, hogy más társadalmak (egyes) tagjai is birtokában vannak vagy lehetnek az engedelmeskedés indokaira vonatkozó kérdezés szabadságának (sőt: mi magunk is sokféle reflektív engedelmeskedési viszonyban lehetünk; s például minden jelentős keresztény egyházban indokolandó és indokolható az autoritás hatalma). Azt sem tagadjuk, hogy ahol nincs ilyen szabadság, ott is létezhet igazgatás, intézményesen koordinált kollektív cselekvés, robusztus uralom: sőt, valójában éppen ez a robusztusság, az engedelmesség magától értetődősége az, ami az államot a modern korban sokfelé oly népszerü politikai megoldássá tette. A lényeg azonban abban van, hogy az állam léte - erősen fogalmazva - politikai provokáció. Mihelyst kimondjuk, hogy létezik - azaz engedelmeskedünk neki -, megkérdőjelezzük a természetességét, magától értetődőségét. S ahogy érvelni fogok, az állam olyan uralmi forma, amely egy jól föltárható, de kétségkívül sajátos és bonyolult politikai érveléssel igyekszik önmagát indokolni. 
Vannak olyan elképzelések is, amelyek az állam uralmát azonosítják a társadalmi, vagy a gazdasági elnyomással. Azok ezt a szabadságot szintén kizárják, pontosabban merő illúziónak deklarálják. Természetesen létezik elnyomás, létezik szabadsághiányos állapot, léteznek erőszakon alapuló uralmi rendek. De ha államról mint uralmi formáról beszélünk, akkor abba beleértjük, hogy az mindenkitől ugyanolyan engedelmeskedést követel meg. Az említett elnyomáselméletekben az elit vagy a kizsákmányoló osztály nincs alávetve az államnak (a neomarxista elméletek éppen abban térnek el a klasszikus marxizmustól, hogy megpróbálnak helyet találni az állam autonómiájának is; kérdés, hogy ez mennyire feszíti szét az eredeti konceptuális keretet); az állam - vagy legalábbis az, amit annak neveznek ezekben a rendszerekben - valóban csak eszköz. Mondani sem kell, hogy az uralomnak mindig van legalábbis potenciálisan elnyomó jellege vagy dimenziója is. Bár az imént nem zártam ki, hogy egy uralom minden igazolás nélkül tartósan fönn tudjon maradni, erre valószínúleg nehéz volna konkrét példát találni (a legstabilabb birodalmak igen fejlett vallási-mitikus legitimációt használnak). Mindenesetre akkor, amikor az államról mint valamilyen mindenki számára egyformán hozzáférhető, s nagyrészt mindenkit egyformán érintő igazoláson nyugvó uralmi formáról beszélünk, akkor a nyugati vagy atlanti civilizáció történetének egy adott időszakában konstituálódó megoldásra gondolunk. Ez tehát a politikai közösség minden tagját magában foglaló, rájuk egyformán vonatkozó, mert mindenki számára azonos problémára választ kínáló uralmi forma. Úgy is fogalmazhatunk, hogy az állam olyan uralmi forma, amely a politikai gondolkodás és elméletalkotás felől nézve egy bizonyos normatív (persze valóságos tényekkel, tapasztalatokkal alátámasztott) konstellációban értelmezhető: abban a konstellációban, amelyet az egyének egyenlősége, természetes szabadsága, korlátozott önérdeke és korlátozott racionalitása határoz meg. Mivel ez az államot megelőzi, éspedig elméletileg is, ezért ezt politikai belátásnak és politikai igazolásnak nevezhetjük. ${ }^{10}$

III.

A következő tézis az állam paradox természetét mondja ki: az állam azonban specifikusan olyan uralomforma, amelyból eltávolitották és eltávolitják a politikát. Csakhogy ez politikai cselekvés, amely politikai cselekvésre ösztönöz.

(Analógia) A magyarázatot hadd kezdjem kicsit messzebbről. A politikaelmélet történetéből jól ismerjük a kereszténység megjelenésének, illetve uralkodó világnézetté, világértelmezéssé válásának elméleti és gyakorlati (intézményi) következményeit. Ennek jól ismert része volt az a döntő fontosságú mozzanat, amit leegyszerúsítve a világi (temporális vagy szekuláris) és az egyházi (spirituális) 
hatalom egymástól való elkülönítésének nevezünk. Az elkülönítés természetesen a politikaelmélet terminus technicusa, amelynek számos magyarázatban nincs is különösebb jelentősége. Itt és most azonban magára a terminusra is reflektálnunk kell. Az elkülönítés ugyanis föltételezi, hogy már meglévő dolgok közé vonunk határt, helyesebben a létező határt mintegy fölismerjük.

Itt azonban nem erről, hanem kölcsönös és sajátos logikájú tételezésről, konstituálásról van - illetve volt - szó. A római köztársaság intézményei, szokás- és jogrendje, kormányzata, politikai logikája (amelyeket még nem nevezhetünk államnak) hosszú, számos esetlegességgel tarkított, s elsősorban a Nyugaton végbemenő folyamat eredményeként nagyrészt megszűnt. Az egyik fontos kivétel viszont éppen a Caesar (inkább: caesar) szerepét megöröklő, az univerzális egységet kifejező politikai szerep, amely szembe találta magát az egyház mint konkrét, szintén intézményesülő, és sajátos törvényekkel, szokásokkal rendelkező közösség egységét kifejező pápai hivatallal. Ez a kettősség az elméletben egymásra utalt, de egymástól valamilyen módon elhatárolt tény gyanánt jelent meg, majd az ismert kettős hatalom (pontosabban hatalom és autoritás) téziseként fogalmazódott meg. De még tovább léphetünk: amikor a tézis megfogalmazódik, valójában nem csak a tényt - az elkülönültséget - rögzíti egyfajta statikus szemléletben, hanem a két hatalom viszonyát logikailag dinamikusnak fogja föl. A spirituális hatalom ugyanis önmagát mintegy viszszavonja (mint kezdeményezőé övé tehát a primátus), az uralomgyakorlás egyes területeit mintegy rábizza a világi hatalomra; misztikusabban fogalmazva: megszüli. A kölcsönös konstituálás értelmében persze a spirituális hatalom is ekkor ismeri föl önmagát ebben a szerepben, tulajdonképpen ilyen módon ébred rá egyáltalán arra, hogy hatalom. Ez a dinamikus elem, vagyis a spirituális hatalom visszavonulása, kivonulása, önmaga eltávolítása a másik oldalról nem megfosztja valamitől, ami az övé volt (hiszen nem is létezett, ezért nem lehetett semmi az övé), hanem eleve ekként hozza létre. ${ }^{11}$

Mármost ha ezt a másik oldalt nem is nevezhetjük még államnak, embrionális formában mégis erről van már szó: a világi hatalom elkülönüléséről, amely azáltal lehetséges, hogy - megfelelő teológiai alapokon - a spirituális hatalom eltávolítja, visszavonja önmagát az emberi, közösségi élet bizonyos vonatkozásaiból, viszonyaiból, rendezéséből. A világi hatalom természetesen nem semleges, nem közömbös a vallással és az egyházzal szemben, erre a megfelelően semleges vagy vallásilag közömbös személyek sem állnak rendelkezésére; de a visszavonulás és a kölcsönös létrehozás számtalan dinamikus (s persze konfliktusos) tapasztalat és esemény révén valóságos folyamat. Még mielőtt az állam mint uralmi forma a politika és a politika visszavonulása által létrejött volna, egy korábbi, több tekintetben vele analóg folyamat azt már előkészítette. Nem is lehet ennek fontosságát eléggé hangsúlyozni, hiszen az analógia révén a következőkben ismertetendő kivonulás vagy eltávolodás/ eltávolítás logikája és konstitutív funkciója talán érthetőbb lesz. 
(Hobbes: az állam in statu nascendi) Jóllehet Thomas Hobbes, ahogy már utaltam rá, nem államelméletet múvelt, mindazonáltal éppen nála és az ő érvelésében lehet a legtisztábban tetten érni a politika visszavonulásának vagy visszavonásának az elméleti stratégiáját, amely egyúttal az állam konstituálása is. Ahogy az gyakran előfordul az elmélettörténetben, egy valós gyakorlati probléma megoldásának fogalmi eszközei nem föltétlenül maradandóak, maga a logika vagy az érvelés azonban igen. A Leviatán metafora (a mesterséges személyé); a commonwealth terminus technicus (ma úgy hívnánk: a szuverén). Egyik fogalom sem azonosítható még az állammal mint uralmi formával, viszont mindkét fogalom egy olyan politikaelméleti okfejtés konklúzióját, eredményét jelöli, amelyben in statu nascendi megpillanthatjuk azt, ami ma államnak hívunk. ${ }^{12}$

Mint tudjuk, Hobbes magyarázata szerint a közhatalom társadalmi megállapodásból születik, vagy legalábbis egy ilyenből levezethető. Ez a megállapodás egyetlen aktus, amelynek lényege az autonóm cselekvésről való kölcsönös és feltétel nélküli lemondás. A megszülető közhatalom negatív cselekvésből ered tehát, hiszen lényege szerint eleve egy visszavonulás miatt keletkezik, kizárólag helyettesítő funkciója van. Viszont a magánéletbe visszavonuló egyének éppen azért mondanak le egymást fenyegető minden hatalmukról, mert pontosan tudják egymásról, hogy nagyon is szeretnének ezzel a hatalommal élni. A hatalommal való élni akarás mint hajtóerő ugyanis nem irtható ki, realitás marad, ezért a közhatalom tulajdonképpeni első feladata nem más, mint küzdés ellene. Ennek a küzdésnek a szervezett változata az uralom, vagyis a közhatalom intézményesülése, s ezt már nevezhetjük államnak. Csakhogy ezek szerint az állam legfontosabb feladata nem az igazgatás, nem a kormányzás, nem a közjó biztosítása, s nem a jogalkotás. A legfontosabb feladat politikai természetû: a hatalom elleni küzdelem. Ez annyiban paradoxon, hogy a hatalommal való küzdelemre az állam éppen egy politikai, hatalmi aktusból nyer fölhatalmazást. De paradoxon ide vagy oda, a végeredmény pontosan abban az értelemben fenntartható megoldás, ahogyan a spirituális és a szekuláris hatalom elválasztása: a megkülönböztetés állandóan probléma, egyben pedig állandó megoldás. A közhatalom tehát úgy alakul állammá, hogy abból a hatalom mint politikai realitás visszavonul; az így létrejövő uralmi forma, az állam ezt a negatív politikai helyet tölti be. Bármennyire is "negatív" ez a hely, mégsem tagadhatja el, hogy politikai eredete van, fő célja pedig az uralom mentesítése, ha tetszik: tehermentesítése a hatalomtól. ${ }^{13}$

(A politikaelmélet feladata) Ennek a konstrukciónak a föltárása és magyarázata eminensen politikaelméleti feladat. Sőt, ennél tovább kell lépnie, ugyanis az említett „hatalom elleni küzdelem” nagyon is valóságos, elméleti és gyakorlati terepen egyaránt folytatott harc. Az elméleti terep az igazolásé: az állam mint uralom politikamentesítése folyton napirenden tartja magát a kérdést, s ezzel végső soron élteti is a politikát, s persze a politikaelméletet is. 
Az államot, pontosabban az államot mint uralmat, uralmi rendet képviselők érvelése mindig ugyanarra utal: az állam létezése az egyedül lehetséges megoldás az anarchia problémájára. Ezért, szólhat az érvelés, az állam egyetlen specifikus problémája - legyen az egy szakpolitikai dilemma, vagy mondjuk a nép vagy a tömegek kormányzásba történő bevonásának optimális mértéke - sem szolgáltatható ki a politikai vitának, hanem állami kompetencia marad. Ennek a negatív érvnek a pozitív formája - mégis, miért kell megtennünk ezt vagy azt, amit az állam kíván; miért kell engedelmeskednünk ennek vagy annak a konkrét elvárásnak, normának, jogszabálynak - a klasszikus hivatkozási alapja az államérdek. Itt nem elsősorban a XVII. századra gondolok, amikor a tömegek bevonása a politikába még eleve elképzelhetetlen volt, hanem a jelenkorra, például a kommunista rendszerekre, ahol a jellemzően az államérdekre, nem pedig a proletariátus uralmára, akaratára, stb. hivatkozva követelték a polgárokról a teljes engedelmeskedést. Az elnevezések - államvédelem, államvédelmi hatóság - ezt jól tükrözték; az eleve autokratikus orosz hagyományok ezt meg is előlegezték (lásd például az Állami Duma-elnevezést). ${ }^{14}$ De már Rousseau forradalma vagy normatív lázadása is felfogható elméleti értelemben az állam elleni politikai lázadásnak: valódi politikai erő rejlik abban a gondolatban, hogy egyetlen normatív aktus vagy parancs sem nélkülözheti a politikai igazolást. ${ }^{15} \mathrm{Az}$ államot meg (vagy éppen vissza) kell hódítani, a politikának fölül kell kerekednie az államon. A cél ugyanis nem az anarchiába való visszatérés, hanem annak a tudatnak a visszaszerzése, hogy politikai beleegyezés nélkül semmilyen állam nem legitim, hogy az államnak politikai eredete van, hogy az uralmat mindig igazolni kell.

Az állam politikamentesítésének politikai feladata folyamatos cselekvést igényel. A természetes módon föllépő és belépni igyekvő gyakorlati politikai érdeklődést el kell hárítania. Az állandó érvényesség tehát folyamatos cselekvéssé, ha tetszik, kvázipolitikai cselekvéssé transzformálódik, amelynek végső politikai célja az, hogy az állam távol tartsa önmagát a politikától. A kora újkori - mondjuk így: konszolidálódó - államokban fogalmazódott meg az a nézet, hogy az állam irányítása, vezetése sajátos múvészet vagy tudás/tudomány (statecraft, Staatskunst, Polizeiwissenschaft, Staatskunde, Staatswissenschaft). Az állammúvészet (Kunst) és az államtudomány mint ismeretanyag (Kunde) tehát annak készsége és tudása, hogy az államérdek éppen mit követel meg, miben áll, hogyan alkalmazandó. Értelemszerúen a közönséges ember erről mit sem tudhat, s a politika nyers és közönséges valósága - amelyet azonban a közönséges ember is jól ismerhet - csak megzavarja, elrontja az állam vezetésének sajátos múvészetét. Ez a tudás a XIX. században demokratizálódott ugyan, de inkább szociológiai értelemben (az érdeklődőket a származás egyre kevésbé zárta ki, legalábbis elvileg, az állam szolgálatából), semmint valamiféle közös tudássá válásként. Természetesen azáltal, hogy az állam a korábbi különféle önigazgatási egységeket magába olvasztotta, ez a közös tudás 
részben létrejött: mindannyian képesek vagyunk adminisztrálni, igazgatni saját magunkat is. De ugyanúgy közismert az igazgatási-jogászi, majd különféle szakértelemmel rendelkező elitek igyekezete nemcsak saját sorainak zárására, hanem a politikával szembeni föllépésére, egészen odáig, a „szakértői kormányzás" helyenként és időnként politikai programmá vált.

A politikamentesítő, politikaeltávolító igyekezet tételünk értelmében azonban politikaösztönző, mi több, provokáló hatással is együtt jár. Radikális forradalmakban olykor teljes igazgatási elitcsere történik, de konszolidált rendszerekben is jellemző politikai program a „bürokrácia csökkentése”, visszavágása, kritikája, a „politikai irányítás” visszaszerzésének igénye. Ezek mögött nem csak bizonyos immanens szempontok merülnek föl (a bürokrácia rossz hatásfokkal múködik, kontraszelektált, maradi, saját érdekeit követi, stb.), hanem - s ez itt a lényeg - léténél fogva provokál. Az állam, illetve képviselője intézkedik, elintéz, akár meg is old; de képtelen arra, hogy megszólítsa vagy bevonja a polgárt bármibe is. Ebben az értelemben az állam mintegy kiváltja (hatásként) a politikát; vagy még pontosabban: a politika által konstituált állam függősége, önigazolásának lehetetlensége föltárul, s ezzel együtt a függőség természetének fölismerésére, az igazolás kérdésének föltevésére ösztönöz.

Erre a kettősségre egy olyan múból idézek egy gondolatmenetet, amely nemigen szokott államelméleti fejtegetésekben helyet kapni. Edmund Burkenek a Töprengések a francia forradalomról címú közismert múvében találjuk azt a nevezetes bekezdést, amelyben a francia forradalmárok (egészen pontosan filozófusok, mai értelemben értelmiségiek) politikai, kormányzati dilettantizmusát taglalja. A bekezdés első mondatában a "science of constructing a commonwealth"-ról mondja, hogy az nem a priori tudomány. Később azt írja, hogy ",i]n states there are often some obscure and almost latent causes," amelyek helyes ismerete összességében - folytatja a következő mondatban - egyfajta "science of government"-nek tekinthető, ami nagyon is gyakorlati tudomány. Ennek elsajátítása és gyakorlása mindenekelőtt tapasztalatot, éspedig az egyes egyén felfogó- és befogadóképességét meghaladó tapasztalatot igényel (Burke, 1951: 58-59.). Kontler László amúgy kitűnő fordításában ebből a három fogalomból - commonwealth, state, government - sajnos csak kettő marad meg, éspedig az állam (amely a commonwealth-et is jelenti), valamint a kormányzat (Burke, 1990: 149). Természetesen nem ragadhatunk le egyetlen bekezdésnél, s azt sem tételezhetjük föl, hogy Burke valami mély és rejtett igazságot akart itt a három fogalom változatos használatával megfogalmazni. Magából az érvelésből (elsősorban a politikaibb tartalmú commonwealth kifejezés alkalmazásából), valamint Burke-nek az egyes egyén képességeit meghaladó tapasztalatra való hivatkozásából azonban két fontos belátásra következtethetünk. Egyrészt arra, hogy az állam nem egyfajta modern, gépezetszerüen összerakható-szétszedhető, tanulmányozható, funkcionális-adaptív eszköz a kormányzáshoz: rendszerint ezt szokták itt kiemelni. Kevésbé figyelnek föl 
a másik következtetésre: tudniillik hogy a kormányzás, az állam irányítása az állammúvészettel, az államérdek képviseletével sem azonos. Olyan tapasztalatok meglétére van szükség, amelyek a társadalmi érdekek és a politika mély ismeretéből fakadnak, s amelyeket végső soron nem lehet kisajátítani. Burke tehát nem csak a kontároktól vagy dilettánsoktól félti a kormányzást, hanem azoktól is, akik szerint ez valóban múvészet, már abban az értelemben, hogy az államban és az államon szabadon élhetik ki a konstruktív fantáziájukat, tetszésük szerint válogatva a lehetséges stílusok között. Nem: az állammúvészet valójában inkább kormányozni tudás, ami pedig leginkább azt a politikai tudást fejezi ki, amelynek része az is, hogy senki sincs a teljes tudás birtokában, még pontosabban pedig mindenki, így a legegyszerúbb polgár is a birtokában van valamilyen tudásnak. ${ }^{16} \mathrm{Ez}$ a minimális tudás is politikai tudás, a legalapvetőbb politikai kérdésre adott válasz ismerete: miért kell engedelmeskednem a törvényeknek, az uralmi rendnek, az államnak. S erre a kérdésre nem lehet azt válaszolni, hogy azért, mert az államérdek, vagy egyszerúen csak az állam ezt kívánja. Ez a válasz ugyanis politikai provokáció, a gyakorlati önkény biztos jele.

A politikaelmélet nem tehet mást, mint hogy folyton fölhívja a figyelmet három összefüggésre. Egyrészt arra, hogy az állam politikaellenessége (küzdelem a hatalom ellen) politikai feladat. Másrészt arra, hogy az állam bármilyen érdeke vagy szükséglete politikaellenes hivatkozás, amely azonban szükségképpen politikai ellenállást indukál. Harmadrészt pedig arra, hogy az államtudomány mint a kormányzásból való kizárás technikája ellenhatalmi technikaként azért hatalmi technika marad. A politikától való megszabadulás, hiába van az államnak mint uralomnak erre politikai fölhatalmazása (eredete), nem tud más lenni, mint politika. A politika éppen ezért állandóan betör az állam sáncai mögé. Hiába Hobbes minden igyekezete, sőt, igazsága abban, hogy az emberek rendszerint különösebb gondolkodás nélkül, ösztönösen, az erőtől való félelem miatt engedelmeskednek, mégis szükségét látta, hogy az állam mint uralom mindenki számára elfogadható, ésszerű igazolását nyújtsa, mégpedig pontosan azzal, hogy a tartalmi igazolás fölöslegességét igyekezett egyszer és mindenkorra bizonyítani. Az állam ugyanis nem szorul tartalmi igazolásra, de nem is volna rá képes. Éppen ezért eleve igyekszik vagy minden igazolási kérdést illegitimmé nyilvánítani, mert potenciálisan anarchiát előidéző; vagy minden filozófiai és uralom-igazolási kérdésben egyformán illetékessé nyilvánítja saját magát. Mondanom sem kell talán, hogy lényege szerint mindkét válasz politikai. S noha a modern demokráciák megadják a politikai részvétel lehetőségét a legtöbb embernek, a képviselet, a politika üzemszerüvé (és alrendszerré) válása vagy változtatása, a pszeudorészvételi formák (állami eszközrendszerrel fönntartott politikai mozgalmak; így szervezett események: népszavazások, demonstrációk, végső esetben választások; kartellpártok) alkalmazása nagyon is hasznos abból a szempontból, hogy a kormányzás 
a gyakorlatban is eltávolodjék a politikától. Minderre, legalábbis Hobbes elképzelésében, van politikai fölhatalmazása az államnak, illetve az állam mint uralomforma ettől legitim. S mégis ez a fölhatalmazás az, amit az állam szeretne titokban tartani (ez a végső, az igazi arcanum imperii); s ez az, amit a politikaelmélet folyton közzé kíván tenni. Ezért van az, hogy az állam, illetve az állam nevében föllépő vezető mindig mély bizalmatlansággal tekint a filozófiára, de kiváltképpen a politikai filozófiára vagy a politikaelméletre.

IV.

A helyzet azonban az, hogy a politikaelmélet nem csupán leleplezi az államot mint lényegi értelemben politikai képződményt vagy konstrukciót, illetve föltárja a hobbesi politikai igazolás logikáját, a politika visszavonását-visszavonulását az uralomból és annak gyakorlásából; hanem igen gyakran az állam szolgálatába is szegődik. Ezzel önmagában még nincs probléma, hiszen sokféle ember sokféle választ vár és fogad el arra, hogy a hobbesi alapvetésen túl van-e egyéb indoka annak, hogy miért kell neki engedelmeskednie. Megjegyzendő egyébként, hogy a Hobbes által kidolgozott igazolás sem tekinthető minden konkrét esetben meggyőzőnek, annak keretein belül elég nehéz igazolni például a hadkötelezettséget, főleg éles háborús helyzetben, hiszen a háború nem föltétlenül nyújt biztosabb túlélési lehetőségeket, pláne egyéni szinten, mint valamiféle anarchia, amelyben csak ki kell várni, amíg a győztes fél megteremti az uralmat. Van tehát tere a politikaelméleti kutatásnak és töprengéseknek. Mindazonáltal, ahogy láttuk, az állam mint uralom politikaelméleti igazolása során két súlyos veszély is föllép. Mindkét esetben megtörténhet (s történelmileg ilyen vagy ehhez közeli gyakorlati állapotok ki is alakultak), hogy az igazolásra vonatkozó kérdések és a kérdezés - a politika - lehetőségét véglegesen fölszámolják. Az egyik eset az igazolási kérdést eleve megelőzni, és így illegitimnek nyilvánítani igyekvő veszély és kísértés, a másik eset az igazolási kérdés megválaszolását illetően önmagát kizárólagosan legitimnek föltüntető veszély és kísértés.

(Rawls) Az előbbire példa John Rawls igazságosság-elmélete (Rawls, 1997). Ennek sokfelé az a híre, hogy ez a par excellence politikai filozófia. A hír alapja, hogy az elmélet kendőzetlenül normatív, a politika, származékosan pedig az állam elé is az igazságosságot állítja végső mérceként. Láttuk azonban, hogy a politikaelmélet megkerülhetetlen alapkérdése az engedelmeskedés, az uralom igazolása. Csakhogy Rawls sem uralomról, sem hatalomról nem beszél, annál többet a jogok, kötelességek és javak elosztásáról. Mármost az alapvető jogok egyenlő elosztása rendszerint nem is vált ki különösebb vitát, ez a megoldás megfelel a hobbesi kiindulópontnak is, bár annál erősebb korlátokat állít 
az uralom elé. Az állam az uralom szervezett formájaként nem terjeszkedhet túl ezeken a korlátokon. A szuverén jogalkotásának még Bodin elképzelései szerint is kemény korlátja a magántulajdon. A politikai jogok egyenlő elosztása pedig további érv amellett, hogy a Rousseau-féle normatív lázadás tanulságai alapján az elmélet igenis megfelel a politikaelmélet elvárásainak. Sőt, még tovább is léphetünk. A nevezetes rawlsi különbözeti elv (difference principle), s a belőle levont elosztási szkéma (az igazságosság második elve) sem kifogásolható, amennyiben egy kormányzat vagy állam éppen erre építi az újraelosztást érintő politikáját. Hobbes sem mondana mást, mint hogy a társadalmi béke érdekében, azaz a társadalomból eredő hatalmi igények és törekvések kezelése (az ellenük való harc) érdekében az állam, illetve az azt irányítók helyesnek láthatják, ha egy ilyen elvre hivatkozva rendezik el az újraelosztás intézményeit. Persze ha a körülmények megváltoznak, az elv lecserélhető.

Tudjuk viszont, hogy pontosan ez az, ami Rawlsnál elképzelhetetlen. Az első lépéstől fogva világossá teszi, hogy számára az alapvető és a származtatott elvek is csak az igazságosság, az igazságos társadalom (commonwealth) felől érvényesek, vagyis az igazságosság eleve adott cél. Márpedig ebben az esetben minden olyan vita, amely ennek a célnak a normatív helyességét érintené, illegitim. A kiindulópont tehát kristálytisztán normatív - ettől politikai filozófiai jellegü az elmélet -, a következmény azonban nem más, mint hogy kiküszöböltük a normatív vitát, s ezzel együtt a társadalmi hatalom, az igazolás folytonos megkérdőjelezésének, ugyanakkor igénylésének és provokálásának a lehetőségét is. Ezzel azonban a politikai filozófia, ha tetszik, a politikaelmélet is megszúnik, legföljebb a kiinduló axiómák alkalmazásain lehet tûnődni, vagy az alkalmazásokat lehet tovább csiszolgatni.

Ahogy említettem, Rawls érdemben sem hatalomról, sem uralomról, sem demokráciáról, sem kormányzásról nem beszél; legalábbis a társadalmi megállapodás vagy szerződés létrejöttekor semmiképpen. Ebben az úgynevezett eredeti helyzetben a résztvevők tehát egy igazságosságelvet állapítanak meg. Nem tételezik föl, illetve Rawls nem teszi, hogy az igazságosságról tipikusan politikai vitát szokás folytatni. Ehhez viszont léteznie kellene a megfelelő politikai közösségnek. Ilyennek a létrehozásával azonban sem ő, sem az általa elképzelt eredeti helyzet résztvevői nem bíbelődnek. A hobbesi kérdést így megkerülve eleve olyan uralmi formát, államot kell elképzelnünk, amely közvetlenül épül az igazságosságra, s ezzel eleve szükségtelenné teszi a politikai vitát, az igazolás kérdését. Az uralomnak igazodnia kell ugyan az igazságosság elveihez, de ezeket az elveket semmi és senki nem kérdőjelezheti meg. Az állam tehát előzetes tiltó normatív hatalommal rendelkezik. Az igazságosságról folytatott vita ugyanis egyúttal azt is tartalmazná, hogy esetleg nem az igazságosság a legfőbb érték vagy elv. Ám mivel ez ellentmond a kiinduló föltevésnek, a normatív vita eleve tilos: ezt jelenti a gyakorlatban a politikaelmélet - saját maga által indított - felszámolása. 
Ennél kényelmesebb helyzetbe az állam mint uralom nem is kerülhetne, hiszen anélkül élvezheti a politikai filozófia nominális támogatását, hogy el kellene számolnia azzal a politikaelméleti kihívással, hogy a normatív vita mindig aktuális, mivel az uralomnak való engedelmeskedés indokára újra és újra rákérdezhetünk.

Nyilván nem arról van szó, hogy Rawls szándéka kimondottan egy totalitárius ideológia megalapozása lett volna, amely egyszerre normatív és antipolitikai. Az azonban föltűnő, amit már említettem, hogy ti. az eredeti helyzetben nincs valódi politika, nincs hatalom, nincs anarchia. A résztvevők decens társadalomból jönnek, mintegy önmagukat elvonatkoztatva, amely nincs még „,jól elrendezve" ugyan, de pontosan ez a cél, azaz a megfelelő elrendezés. Egyébként még egy ilyen, viszonylag rendezett állapotból is tovább lehetne lépni, mondjuk egy locke-i érveléssel, amely az egyenlő alapvető jogokat nem az igazságossággal, hanem a szükséges minimális autonómiával és annak védelmével köti össze. A társadalmi megállapodás pedig az állam határairól szól vagy szólna, mert a locke-i (de nem hobbesi) föltevés az, hogy az állam határtalansága okozná a legnagyobb rendetlenséget, azaz önkényuralmat. De Rawlst ezek a lehetőségek nem érdeklik. Az elrendezés nála az összes társadalmi, emberi alapviszony alávetését jelenti egy olyan értéknek, amely korlátlanul érvényesül, mégpedig az állam közvetlen vezérlésén keresztül. Az uralom igazolása - a politikai filozófia definitív témája - helyett egy morális-politikai érték igazolását mutatja be. Így az államot, vagy az azt irányító kormányzatot, politikai vezetését megszabadítja az uralom igazolásának a politikán kívül megoldhatatlan problémájától. Ez az eljárás éppen politikai sikerei alapján leplezi le saját magát: a rawlsi állam semleges kíván lenni ugyan a jóra vonatkozó sokféle nézet között, kizárólagos értékorientációja miatt a valóságban rendkívül korlátozó és doktrinér, hellyel-közzel politikai értelemben elnyomó.

(Állammisztika) A másik kísértés az a koncepció, amelynek egyik oldalát nevezhetjük állammisztikának, a másik oldalát pánpolitikának. Ez magát az államot tekinti olyan értéknek, amely mint érték igényel igazolást. Ez a felfogás, sajnos vagy nem sajnos, minduntalan fölsejlik az államelmélet hagyományos (esszencialista, sui generis) elképzelései mögött is, még akkor is, ha inkább jogilag semleges, nem pedig vérbő filozófiai nyelvezetet használnak. Ez a koncepció, amelynek számtalan változata van, főleg a német gondolkodást határozta meg. Bár ebben a formájában ma nem tekinthető divatosnak, egyrészt hordereje rendkívüli volt, másrészt pedig, ha az államelméletet a politikaelmélettől elválasztva kívánjuk múvelni, akkor ezek a gondolatok óhatatlanul vissza fognak térni, éspedig inkább előbb, mint utóbb. ${ }^{17}$ Az alapgondolat értelmében tehát az államnak nincs szüksége arra, hogy bármilyen külső politikai vagy morális igazolást keressen magának, mert az igazolás magából az államból, az államról való gondolkodásból, ha tetszik: az államelméletből ered; 
S végső soron az állam valamilyen apriori megértésénél lyukad ki. Hangsúlyozom, hogy ez nem az államérdek tanának visszatérése, mert az, ahogy megmutattam, végső soron éppen az igazolás igényének visszautasítása. Itt azonban nagyon is fontos az igazolás. A politikaelméletet, de tágabban véve a teljes filozófiát igénybe lehet venni, tetszés szerint emelve ki belőle különféle ötleteket arra nézve, hogy az állam lényege miben is áll.

Akármilyen konkrét megoldásra is jutunk, a következmény az lesz, hogy mivel az állam létezése érték, sőt, önérték, magában hordja az igazolását, s így szorosan véve az állam marad az egyetlen politikai cselekvő, vagy legalábbis a legteljesebb értelemben vett, legtökéletesebb, kvintesszenciális politikai cselekvő (a jog nyelvén: az állam alkotja a jogot). Az állam mint uralmi forma tökéletesen és végérvényesen legyőzi a hatalmat. Az állam a politikai akaratot közvetlenül képviseli vagy fejezi ki. A politikai akarat többé nem csak arra irányul, hogy legyen uralom, hanem arra is, hogy ez az uralom minden rezdülésében, mozdulatában, aktusában látszódjék, megtestesüljön. Szó sincs arról, hogy az államnak mintegy mentesítenie kellene magát a politikától, ellenkezőleg: azonossá kell válnia vele, hordoznia és képviselnie kell az összes olyan értéket, amely a politikai közösségben egyáltalán elgondolható.

Ezt sok szempontból a legegyszerúbb úgy megoldani, hogy az állam mintegy közvetlenül is megtestesül például egy politikai vezérben, annak akaratában, ahogyan azt Carl Schmitt ki is fejti (Schmitt, 2002). A vezér bármely elgondolása, elképzelése így ugyanis közvetlenül fejezi ki a politika egyedül lehetséges irányát, valamint ezzel egyidejüleg az államnak mint eszköznek is látható, követhető gazdája van. Nincs szükség bonyolult és elvont fogalmak használatára, a megszemélyesítés mindig is a legegyszerúbb uralomgyakorlási módszerek közé tartozott.

Politikai fölhatalmazás és végleges, kizárólagos normatív igazolás birtokában önmagát a politikától és a hatalomtól elszakító állam elképzelésével szemben itt tehát az önmagát a politikával azonosító állammal van dolgunk, amelyből azonban ugyanúgy hiányzik az uralom, a kényszer, az engedelmeskedés igazolása. A politikai dimenzió egy másik módon, de szintén elillan. A valóságban persze nem, hiszen az uralom és az engedelmeskedés kényszere akkor is tény marad, ha a politikai vezér a maga akaratát tényleg képes az állam teljes apparátusán és struktúráján végigfuttatni, s ezt azzal a meggyőződéssel tenni, hogy a politikai közösség politikai akaratát képviseli vagy hajtja végre. Az állam ugyanis uralom, igazolásának lényege pedig, ahogy érveltem, éppen a hatalom kiiktatása, eltávolítása az uralomtól. Ez pedig természetesen mindig politikai cselekvés, még ha negatív is. Ezért a hatalom és vele együtt a politika mindig betör az állam és uralom sáncai mögé. Az állam esetleges uralmi forma, kontextushoz, civilizációhoz kötött politikai igazolási stratégia, amely a gyakorlatban lehet sikeres, de soha nem kizárólagos. A kizárólagosságra való törekvés tehát érthető politikai ösztöne az államnak, amely éppen ezért mindig 
megtalálja a maga politikai (ki)használóját. A politikaelmélet pedig könnyen kísértésbe esik, mert vagy úgy látja, hogy egy abszolút érvényességű elv révén végleg meghódíthatja az államot és az uralmat (ez ugyanakkor az állam kísértése is); vagy úgy találja, hogy fölösleges a különböző igazolási módokkal bíbelődnie, hanem csak meg kell adnia az általános fölhatalmazást az állam számára ahhoz, hogy uralmát egyszerúen azzal igazolja, hogy a politikai kérdést már akkor végleg eldöntötték, amikor az államot egyáltalán megalkották. Ha azonban az uralom igazolásának pluralizmusát, amely a politika alapproblémája, egy állam úgy igyekszik megoldani, hogy átveszi az igazolás összes terhét, abból nagyon más nem tud következni, mint egyfajta állammisztika, amely csak két opciót ismer: azonosulást és elutasítást. A politika inherens igazolási pluralizmusát mindkét opció kizárja, s vele együtt a politikaelméletet is fölszámolja.

\section{JEGYZETEK}

${ }^{1}$ Ahogy az állam, úgy a politikai gondolkodás terminus is modern. Platón, de főleg Arisztotelész felfogása a tudás különféle fajtáiról igen összetett. A politika ügyeiről való gondolkodásnak része, hogy a megszerzett tudás milyen fajtájú, azaz hogyan viszonylik a cselekvéshez és más tudásformákhoz. Nem témája ennek az írásnak, de fontos volna például, ha az államról szóló vitákban az államról szóló tudás mibenléte, a tudás megszerzésének mikéntje, módszere is szóba kerülne. A mértékadó könyvekben - lásd a következő lábjegyzetet - ennek nincs nyoma.

2 Takács Péter elég világosan el is ismeri, hogy az állam kifejezetten modern jelenség. (Takács et al., 2016: 11-13.). Igaz, egy másik - legalábbis részben szintén általa szerkesztett - államelméleti tankönyv erre már nem figyelmeztet, hanem Platónt, Arisztotelészt is besorolja az államelmélet múvelői közé (Egresi et al., 2016). Samu Mihály értékelése, hogy az antik gondolkodásban a társadalom és az állam mintegy felcserélődik, ebben a formában ugyancsak anakronisztikus (Samu, 1992: 12.). Ó maga is hangsúlyozza ugyan, hogy a visszavetítés helytelen, de hozzáfúzi, hogy azért elképzelhetőek olyan „egzakt eredmények, amelyeket az adott kor leírásaiban és következtetéseiben találunk" (uo.). Ezzel is egyetérthetnénk, föltéve, hogy ezek az eredmények kellően árnyalt és problémaközpontú elemzésekbe illeszkednek.

${ }^{3}$ Implicit módon hasonló állítást Samu Mihály is megfogalmaz: „Az államtudományok szerepét és feladatait a különböző eszmei irányzatok más és más megközelítés alapján határozzák meg: nyilvánvalóan más választ adnak erre a konstitucionalizmus, a liberalizmus, a szocializmus, a konzervativizmus, az etatizmus, a nacionalizmus vagy a fasizmus irányzataiban és koncepcionális magyarázataiban" (Samu, 1992: 11.). Ezek szerint ugyanis az államelmélet függő változó.

${ }^{4}$ Takács Péter Georg Jellinek fejtegetéseit idézi, aki szerint az uralom társadalmi, a hatalom állami (de nem politikai) jelenség (Takács et al., 63.). Jellinek természetesen az állam és a politika szoros fogalmi összetartozását tanította: a politika állam nélkül nem gondolható el; a politika valójában alkalmazott államtudomány (Jellinek, 1914). Nem itt van a helye Jellinek elemzésének, annyit viszont érdemes róla elmondani, hogy számára a már említett anakronizmus a legcsekélyebb problémát sem okozza. Nála a politikai gondolkodás összes klasszikusa államelmé- 
letet múvelt. Például Hobbes Leviatán-elmélete is államelmélet, a társadalmi szerződés pedig értelemszerúen államalapítás. Tudvalevő, hogy Hobbes nem használja az állam kifejezést, hanem commonwealth-et mond (a magyar fordításban ez minden magyarázat nélkül 'állam'). Hobbes persze nem azért mellőzi az állam kifejezést, mert valamiért nem ismeri, hanem azért, mert az állam, ahogyan ma értjük, nem is létezett.

${ }^{5}$ Weber uralomkatalógusa is lehetne politikaelmélet, nagyjából úgy, ahogyan Arisztotelész alkotmánytana is az, ha Weber nem igyekezett volna - tudományetikai meggyőződésből - mindenáron eltávolítani belőle a normatív elemet. Ez persze fogalmilag lehetetlen, így azt a megoldást választotta, hogy minden uralomdefinícióban szerepelteti a hit vagy a meggyőződés elemét. A karizmatikus uralom akkor az, ami, ha a vezető karizmájában hisznek. A bürokratikus uralom az, ahol az intézmények, eljárások, jogrendszer helyességében hisznek. Karizma és helyesség persze inherensen normatív fogalmak.

${ }^{6}$ Cs. Kiss Lajos megfogalmazásában: „A proletárdiktatúra akciócentrumát jelentő Párttal szemben az elhalásra ítélt Államot, mint »történelmi kategóriát« önálló tudományos problémaként kutató államtudomány feleslegessé, ideológiailag veszélyessé vált, amelyet tudománypolitikailag semlegesíteni kellett.” (Cs. Kiss, 2017: 5.) Az „akciócentrumot” itt a nyugodt lelkiismerettel azonosíthatjuk a valódi és egyetlen politikai cselekvővel, ami tényleg nem az állam. Így az államtudomány megszüntetése voltaképpen politikailag hiteles cselekedet volt, nem pedig, a szerző sugalmazásával némiképp ellentétben, valamiféle erőltetett és hiteltelen ideologizálás. Mármost igaz, hogy mindig is voltak olyan tudósok (az itt tárgyalt államelmélet-könyvek szerzői, szerkesztői minden bizonnyal közéjük tartoznak), akik az államtudományt tudományos megfontolásokból vélték visszaállítandónak. Mégsem lehet maradéktalanul egyetérteni a szerző értékelésével, mely szerint a Nemzeti Közszolgálati Egyetemen az Államtudományi és Közigazgatási Kar újraalapítása és az „Államtudományi” osztatlan mesterképzési szak indítása visszaadta az államtudomány autonómiáját. Ezeket a döntéseket ugyanis egyértelmúen a politika, s nem a tudomány elvárásai szerint hozták meg, s ezt kivételesen egészen egyértelmú bizonyíték támasztja alá: az államtudományi képzés folytatását a törvény csak az NKE számára teszi lehetôvé. Ezért bármennyire is sajnálatos, az államtudomány mint egyetemi diszciplína, szak, Magyarországon politikai érdekágyban fogant és született újjá. Talán nem érdektelen adalék a jelen folyóirat olvasói számára, hogy a szak elvégzése doktori fokozatra jogosít, melynek latin megnevezése doctor rerum politicarum.

${ }^{7}$ A már idézett államelméleti tankönyvek leginkább erre szorítkoznak. Egyik anonim bírálóm fölveti, hogy bár érvelek amellett, hogy a politikaelmélet számára az állam uralmi-hatalmi jelenségként értelmezendő elsősorban (de nem kizárólag), számára ez nem elég érthető. Erre sajnos itt csak azt tudom válaszolni, hogy a politikaelmélet Platón óta gyakorlatilag ezt, vagyis az engedelmeskedés helyes indokának keresését föltétlenül központi kérdésként kezeli, s innen nézve az államra sem tekinthet másként.

8 Önmagában rokonszenves kísérlet Bódig Mátyás és Győrffy Tamás kétkötetes államelmélete (2002). Ók ugyanis világossá teszik, hogy az államelméletet a politikai filozófia felől közelítik meg, azaz a normatív aspektust is komolyan veszik. A politikai filozófia nem ideális gyakorlati elmélet, hanem létező intézmények létének gyökerét, elvét keresi és értelmezi úgy, hogy az igazolás sem túnik el belőle. Számukra a mérsékelt állam a vonzó, amelyet az állam egy struktu- 
rális változatának neveznek. Nem állítják, hogy a korlátlan állam nem is állam, de a helyzet az, hogy akár ezt is megtehetnék. A pontos határok meghúzása részletkérdés; viszont érdemes fölidézni, hogy a Jogelméleti Szemlében lezajlott eszmecsere során Bódig Mátyás például határozottan ebben a szellemben értelmezi saját könyvük alapálláspontját: a totalitárius állammal szemben a mérsékelt állam lehet liberális, konzervatív, szociáldemokrata - már amennyiben az ideológiai jelzőknek itt van értelmük (Bódig, 2004). Ami viszont mégis nehézkessé teszi a szerző- és szerkesztôpáros koncepcióját, az az elemzés tárgyának a rendszertelensége, az autoritás esetleges kiemelése a tágabb engedelmességi viszonyok közül.

${ }^{9}$ Cs. Kiss Lajos az államelmélet hét kutatási irányát különbözteti meg: egy német-osztrák hagyományt követő általános államtant; a „politikafilozófiai kutatási irány”-t; egy jogi-politikaelméleti értelemben semleges megközelítést; a természetjogit; az alkotmányjogit; a politikatudományit; s végül a társadalomelméletit. Van, amelyik ezek közül végső soron illegitim, amennyiben az államot és vele együtt az államtant föloldja valami másban, s így relevanciáját megszünteti. Ezeket most nem értékelem külön-külön. (A politikatudományiról fentebb volt szó; a szerző értékelésével egyet lehet érteni, hozzátéve, hogy politikaelméleti szempontból abban a politika szférájának elkülönítése és föltételezett elkülönülése is vitatható, illetve a funkcionalista társadalomelmélet premisszáiból adódik.) Viszont röviden jeleznem kell, hogy a szerző a politikafilozófiai kutatási irányt indokolatlanul köti a jogelmélethez: „[e]z a kutatási irány a jogelmélet politikafilozófiai megalapozásának összefüggésében, azaz a jogelméleti kutatási program részeként, igazolás- és intézményelméleti nézőpontból került sor önálló államelmélet kidolgozására, a joguralom-tan teoretikus változataként. A kutatási irány alaptézise: a jogelmélet nem az államelméletből, hanem »alapvetően a politikai filozófiából meríti teoretikus energiáit«, s abból kell kiindulnia, hogy a jog, mint politikai intézmény kifejtéséhez nincs szükség az államelméletre, mint önálló konstrukcióra. Ebből az következik, hogy az állam fogalmi megragadása kizárólag a politikafilozófia által vezérelt jogelmélet feladata." (Cs. Kiss, 2017: 12. A belső idézet Bódig Mátyás egy másik írásából van.) Álláspontom szerint a politikai filozófiának nincs szüksége a jogelmélet közvetítésére, hogy az államról tudományosan és filozófiailag értékelhetô állításokat tegyen. Egy jogfilozófus természetesen szabadon élhet a politikai filozófia eszköztárával, de ez nem tudományos, hanem személyes döntés, amit éppen ezért nem szerencsés irányzatként definiálni. A jelen írás sem foglalkozik a jog filozófiájával.

${ }^{10}$ Az egyenlőség az államelméletben az állampolgárság fogalmát előzi meg. A természetes szabadság az állam határoltságát implikálja. A korlátozott önérdek arra utal, hogy az állam mint uralmi forma a közérdekre is irányul, amelyet leginkább valamilyen közjó, közösségi jó módjára fogunk fel. A korlátozott racionalitás pedig az állam szakszerűségét, erősebb kompetenciáját alapozza meg, legalábbis bizonyos kollektív dilemmák és konfliktusok megoldásában. Ezek persze történetileg kialakuló, megszilárduló föltevések; a korai, a rendiségből az abszolutista megoldások felé haladó uralmi forma nem egyik napról a másikra alakult állammá.

${ }^{11}$ A Politikatudományi Szemlében talán szokatlan gondolati-fogalmi formák ezek. A teológiailag képzett olvasó minden bizonnyal fölismeri bennük a skolasztikus trinitológiával való analógiát. Azt azonban jól tudjuk, hogy Carl Schmitt megfigyelése a teológiai és a politikai gondolkodás közötti analógiákkal kapcsolatban mennyire termékenyítő hatásúnak bizonyult. Ha óvatosan is, de megkockáztathatjuk, hogy a kölcsönös konstituálás, az ontológiai primátus, valamint a re- 
latív elkülönülés koncepciójának mélyebb szinten köze van az egység-háromság értelmezésének hagyományához is.

${ }^{12}$ Maurizio Viroli klasszikus múvében bemutatja azt az eszmetörténeti, egyúttal politikatörténeti folyamatot, ahogyan az itáliai politikai gondolkodásban a politikát fölváltja az állam, az államérdek (Viroli, 1992). A jelen tanulmányban nem elmélettörténeti rekonstrukció a célom, hanem normatív-analitikus. Másként fogalmazva: nem Hobbes gondolkodása, hanem érvei és gondolatmenetei a fontosak.

${ }^{13}$ Az állam politikai „eredetének” hangsúlyozása éppen a német államelméleti hagyományon belül volt forradalmi gondolat. Carl Schmitt tézisét részletesen elemezni itt nincs hely, annyit azonban a magyar kontextus szempontjából érdemes megjegyezni, hogy Cs. Kiss Lajos, Schmitt egyik legjobb és legértőbb hazai elemzője, az idézett államelméleti tanulmányában meglehetôsen sajátos módon alkalmazza Schmitt belátásait. A konklúzió ugyanis így szól: „Az állam mindig jogállam, azaz mint intézmény eleve jogrendként is létezik, de nemcsak jogból [...] áll, nemcsak jogi funkciója van, hanem van egy, a jogból nem levezethető politikai alkotórésze és létszerú funkciója. A kettő nem választható el egymástól, csak együtt elgondolva lehet az államot tárgynak megfelelően azonosítani és róla teljes leírást adni. Azonban az állam politikai, jogitól független alkotórésze és funkciója csak a kivételes állapotban, illetve a modern totális állam strukturális helyzetében válik láthatóvá és megismerhetővé" (Cs. Kiss, 2017: 26.). Ezzel így nem lehet egyetérteni: az államnak nem része a politika, sem elemként, sem funkcióként; főleg nem úgy, hogy mellérakva mintegy a jogit, megkapnánk magát az államot. Persze egy adott államban létezhet politikaiként azonosított intézményrendszer, de az legalább annyira a társadalomnak, sőt, a politikai közösségnek is a része. Mindazonáltal ha az, amit politikainak nevezünk, az államon kívül nem létezhetne, akkor nem volna értelme annak, ami Schmitt alapvető fölismerése, hogy ti. a politikai fogalma megelőzi az államot. Más kérdés, hogy a „politikai" fogalmi primátusa mit jelent; saját álláspontom az, hogy itt nem fogalmi búvészkedésről, hanem valóságos, ontológiai primátusról van szó, vagyis arról a valós helyzetről, ami az engedelmeskedés indokának megadásáról, megállapításáról, tisztázásáról szól. Schmitt maga nem tette föl ezeket a kérdéseket; jó okkal. Pontosabban: megvoltak a maga személyes politikai indokai. A lényeg tehát: a politika, s vele együtt a politikaelmélet kívülről is képes az államra reflektálni, s ez feladata is.

${ }^{14}$ Szúcs Zoltán Gábor hívta föl a figyelmemet arra, hogy az államvédelem, államrendőrség kifejezések a dualizmusból erednek, és a Horthy-rendszerben teljesednek ki. Ezek a német modell követésén túl a helyi hatóságok ellenpontját fölépíteni igyekvő politikai kormányzatok intencióit és igyekezetét is tükrözték.

${ }^{15} \mathrm{Az}$ „erősebb joga” önellentmondás. Az engedelmeskedés az erőnek természetes reakció, amely az erő hatásáig tart, de nem elv. Az engedelmeskedés tartósságához jogosság - igazolás - kell tehát, de ez nem lehet az erő, akkor sem, ha az éppen az állam kezében van (Rousseau, 1978, 470-471.).

${ }^{16}$ A gondolatot az is alátámasztja, hogy a brit common law ismert induktív-precedentális logikája egyszerre tartalmazta a tapasztalat fontosságát és a helyi összefüggésekre, a konkrét esetre koncentrálás fontosságát. A megjegyzésért köszönet Szúcs Zoltán Gábornak. 
${ }^{17}$ A klasszikusok közül Fichtét és Hegelt talán idézni sem kell. Példaképpen J. G. Fichte egyik írását mégis érdemes elővenni. A felvilágosodás gondolatvilágának megfelelően ő az ész vagy értelem uralmával azonosítja a tökéletes államot, amely az emberiség célját szolgálja (Fichte, 1981). Kifejti, hogy az állam számára mindenekelőtt nem jogi, hanem filozófiai fogalom, s inkább „abszolút államról” beszél, amely „arra szolgál, hogy az összes egyéni erőt a nem [ti. az emberi nem] életére fordítsa, s abba olvassza fel, tehát hogy az egyénekben kívülről megvalósítsa és megjelenítse az általában vett eszme [...] formáját" (572. o.). Ez persze egyelőre kényszer; de az értelem korában az állam megszúnik külső-kényszerítő erő lenni, „belülről átjárja a polgárt” (648. o.). A rousseau-i politikaelmélet, vagyis a köztársaságelv és társadalmi szerződéselv Fichténél magától értetődő könnyedséggel megy át államelméletbe, amelynek logikus konklúziója az, hogy a tökéletes állam a tökéletesen, azaz racionálisan kétségbevonhatatlanul igazolt uralom, amelyben a polgárok minden erejükkel önként szolgálják a közösség javát, s többé föl sem merülhet az a kérdés, hogy az ember esetleg nem szabad. Rousseau föllázadt az államérdek ellen, a politikai igazolást követelve; de az igazsághoz hozzátartozik, hogy mindkét szélsőséges megoldást, amely a politikaelméletet az állam szolgálatába állítja, minden további nélkül le lehet vezetni a fejtegetéseiből.

A I. világháború után a felvilágosodás programja helyett a részben nietzschei ihletésú elitista, kiválasztottságon, nemességen, szellemi-faji felsőbbrendűségen alapuló uralom elméletei keretezték a tökéletes állam tanát, jól jelezve, hogy az éppen aktuális filozófiai trendek milyen könnyen használhatók ki az állam „lényegi” vagy apriori meghatározásában. Lásd például Othmar Spann (1921) könyvét. Nála „szellemi érvényesség” teszi az elitet a legjobbá, a legtökéletesebb állam pedig a legjobbak vezetését jelenti (203-205.).

A magyar eszmetörténetben a Szent Korona-eszme egyes értelmezései vagy koncepciói mutatnak hasonló irányt; továbbá azok a nézetek, amelyek az „államalkotó-képesség”, az állam vezetésére való "történelmi hivatottság” és hasonló fogalmak révén közelítették meg a magyar „államiság”-ot.

\section{IRODALOM}

Bihari Mihály-Pokol Béla (2009): Politológia. Budapest, Nemzeti Tankönyvkiadó.

Bódig Mátyás-Győrffy Tamás (2002): Államelmélet. A mérsékelt állam eszméje és elemei. I-II Miskolc, Bíbor.

Bódig Mátyás (2004): Cs. Kiss Lajos és a mérsékelt állam interpretív elmélete. Jogelméleti Szemle, 4. Burke, Edmund (1951): Reflections on the French revolution, London, Dent, New York, Dutton, 1951.

[A magyar változat: Töprengések a francia forradalomról, Budapest, Atlantisz-Medvetánc, 1990.]

Cs. Kiss Lajos (2017): Államtudományi helyzetkép. Államtudományi Mưhelytanulmányok, Budapest, Nemzeti Közszolgálati Egyetem, 6: 2-39.

Egresi Katalin-Pongrácz Alex-Szigeti Péter-Takács Péter (szerk.) (2016): Államelmélet. Győr: Széchenyi I. Egyetem.

Fichte, Johann Gottlieb (1981): A jelenlegi kor alapvonásai. In: Válogatott írások. Budapest, Gondolat. Jellinek, Georg (1914): Allgemeine Staatslehre. Berlin, O. Haering. 
Rawls, John (1997): Az igazságosság elmélete. Budapest, Osiris.

Rousseau, Jean-Jacques (1978): A társadalmi szerződésről. In: Értekezések és filozófiai levelek, Budapest, Helikon, 463-618.

Samu Mihály (1992): Államelmélet, Budapest, Püski.

Schmitt, Carl (2002): A Führer oltalmazza a jogot. In: A politikai fogalma. Budapest, Osiris-PallasAttraktor, 227-231.

Spann, Othmar (1921): Der wahre Staat. Leipzig, Quelle \& Meyer.

Takács Péter-H. Szilágyi István-Fekete Balázs (szerk.) (2016): Államelmélet. Budapest, Szent István Társulat.

Viroli, Maurizio (1992): From politics to reason of state. The acquisition and transformation of the language of politics 1250-1600. Cambridge, Cambridge University Press. 